\title{
Arsenic contamination in shallow groundwater and agricultural soil of Chakdaha block, West Bengal, India
}

\author{
Anamika Shrivastava, Anil Barla, Himanshu Yadav and Sutapa Bose* \\ Environmental Science Research Laboratory, Department of Earth Sciences, Indian Institute of Science Education and Research Kolkata, Nadia, India
}

\section{Edited by:}

Ramanathan Alagappan, Jawahralal Nehru University, India

\section{Reviewed by:}

Nahuel Francisco Schenone,

Fundacion Bosques Nativos

Argentinos para la Biodiversidad,

Argentina

Jiri Faimon, Masaryk University,

Czech Republic

Ratan Kumar Dhar, York College,

City University of New York, USA

\section{${ }^{*}$ Correspondence:}

Sutapa Bose, Department of Earth Sciences, Indian Institute of Science Education and Research Kolkata,

Mohanpur (Kalyani) 741246, Nadia,

West Bengal, India

e-mail: sutaparai@gmail.com
The study area comes in one of the eight districts of West Bengal where groundwater contains arsenic above the prescribed limit by WHO $(10 \mu \mathrm{g} / \mathrm{l})$. Each day groundwater is being withdrawn by the village people for the fulfillment of their basic needs and for agricultural purposes. With the groundwater along with high concentration of arsenic (As), many other heavy metals are also getting introduced in the environment. In the areas with a long history of use of such groundwater, the agricultural lands have been affected severely. The extent of contamination has increased to a level where the crops grown in those lands are becoming a major source for arsenic and other heavy metals poisoning and subsequently transfer to different trophic levels. Based on this concern a somewhat detailed study was carried out to obtain an idea about the magnitude of soil and water contamination in the area. The mean concentrations $(\mathrm{mg} / \mathrm{kg})$ of As (9.67), Fe (9275.58), $\mathrm{Mn}$ (190.04), $\mathrm{Cu}$ (26.53), and $\mathrm{Zn}$ (36.04) in the control land soils were found within the normal range. Whereas the mean As (54.40), Fe (15745.50), Mn (307.90), Cu (69.33), and $\mathrm{Zn} \mathrm{(44.56)}$ were found to be in higher, mainly arsenic which is at an alarming point. In case of water samples, the pond water was having the mean concentration ( $\mu \mathrm{g} / \mathrm{l})$ of As (32.63), $\mathrm{Fe}$ (57.21), $\mathrm{Mn}$ (30.25), $\mathrm{Cu}$ (0.82). Whereas in case of shallow groundwater there was more increase in the case of As (76.43), Fe (5493.22), Mn (253.63), and $\mathrm{Cu}$ (1.82). It was also observed that $\mathrm{Zn}$ although present in soil samples, it was below detection limits in case of water samples. The As concentration in soil and water showed a positive correlation. Also the correlation analyses between soil arsenic and other heavy metals shows a positive co-relation with all of them.

Keywords: shallow groundwater, heavy metals, rice paddy, contamination, accumulation

\section{INTRODUCTION}

Groundwater is an important natural resource for domestic and industrial water supply as well as agricultural purposes. But the over exploitation of groundwater resources especially As contaminated groundwater is now the major concern to health safety and the sustainable agriculture. The natural occurrence of arsenic in groundwater constitutes a major setback in the provision of safe drinking water to millions of people in Asia and worldwide (The World Bank, 2005). This issue makes a wide range of problems in terms of water quality as well as quantity and it is emerged during the past three decades. Arsenic is by far one of the most toxic elements in the environment (Cullen and Reimer, 1989; Dermatas et al., 2004; Hudson-Edwards et al., 2004) and is responsible for the highest risks of morbidity and mortality worldwide, both because of its toxicity and the number of people exposed (Hopenhayn, 2006). The World Health Organization (WHO, 2007) permissible limit for arsenic is $0.01 \mathrm{mg} / \mathrm{l}$ for drinking water and $\mathrm{FAO}$ permissible limit is $0.10 \mathrm{mg} / \mathrm{l}$ for irrigation water (Bhattacharya et al., 2009; Ahsan and Del Valls, 2011). Whereas the concentrations of As in non-contaminated soils range from 0.1 to $10 \mathrm{mg} / \mathrm{Kg}$ (Kabata-Pendias and Pendias, 1992). The immediate and long-term impact of using As contaminated water for irrigating paddy soils is a burning concern as arsenic can transfer from water to soil and several studies have proven this phenomenon.

Many Asian countries are known to be affected by high groundwater As concentrations as a result of chemically reducing aquifer conditions. The estimates of the rural population exposed to unsafe As levels by drinking untreated groundwater in India, China, Myanmar, Pakistan, Vietnam, Nepal, and Cambodia have grown to over 100 million (Ravenscroft et al., 2009). In India Arsenic is naturally derived mainly from eroded Himalayan sediments, and is believed to enter in the solution following reductive release from solid phases under anaerobic conditions (Polizzotto et al., 2008). And within basins, it follows that arsenic release from Himalayan-derived sediments will be initiated at the point, in time and space, corresponding to the aerobic-anaerobic transition (Winkel et al., 2008; Fendorf et al., 2010). But there is uncertainty in the pathways which is partly attributed to a poor understanding of groundwater flow paths mainly altered by extensive irrigation pumping in the Ganges-Brahmaputra delta (Fendorf et al., 2010). Although many authors have reported arsenic-rich pyrite in the sediment samples of Ganges delta of West Bengal (Das et al., 1996; Roychowdhury et al., 1999; Chakraborti et al., 2001). Some authors also have argued that arsenic is mobilized by slow reduction of iron oxyhydroxides or 
sorbed arsenate by detrital organic carbon (Nickson et al., 1998). Whereas others have suggested that arsenic may have recently been released through sulfide oxidation reactions that is induced by the massive increase in dry-season irrigation pumping (Das et al., 1995; Chowdhury et al., 1999). Though the exact chemical conditions and reactions leading to As mobilization are still under debate, it is generally assumed and accepted that microbial and/or chemical reductive dissolution of As-bearing iron minerals in the aquifer sediments is the main cause for the release of As (Winkel et al., 2008).

It is also studied that the important factors affecting As chemistry and its mobility in soils are soil solution chemistry ( $\mathrm{pH}$ and redox conditions), solid composition, As-bearing phases, adsorption and desorption, and biological transformations, volatilization, and cycling of As in soil (Sadiq, 1997; Goh and Lim, 2005). Moreover, organic content, soil fractions and oxides of $\mathrm{Al}$, Fe, and $\mathrm{Mn}$ also affect the amount of As in soil (Chauhan et al., 2012). Also metal sulfide, temperature, salinity, distribution, and composition of biota appear to be significant factors for determining the fate and transport of As (Ning, 2002). Fixation of As with iron oxide surfaces is an important reaction in the subsurface soil as iron oxides are widespread in the nature as coatings on other solids, also because arsenate adsorbs strongly to iron oxide surfaces in acidic and near-neutral $\mathrm{pH}$ conditions (Ahsan and Del Valls, 2011). Apart from these, there may be additional factors that could add further complication to potential arsenicrelease mechanisms from sediments. These factors may include the predicted mobilization of sorbed arsenic by phosphate generated from the intensive use of fertilizers in the agricultural fields (Acharyya et al., 1999), or by carbonate produced via microbial metabolism (Appelo et al., 2002; Harvey et al., 2002), or by changes in the sorptive capacity of ferric oxyhydroxides (Smedley and Kinniburgh, 2002).

Presently, the extent of groundwater arsenic contamination in West Bengal has reached an alarming situation as nine districts of West Bengal have been reported to have groundwater arsenic concentrations above $50 \mu \mathrm{g} / \mathrm{L}$ and several people have been affected by arsenic poisoning (Chakraborti et al., 2009). With time the concern for arsenic and other heavy metals contamination of soil and groundwater and its transfer to human and other forms of lives through agriculture and other means has gained much attention. It is seen that the total exposure of arsenic to humans and animals is the sum total of exposures from the diet, drinking water, direct ingestion of soil and dust, inhalation, and percutaneous absorption (WHO, 2000; Hopenhayn, 2006). Whereas food represents a further potential exposure pathway to arsenic in instance where crops are irrigated with high arsenic groundwater, grown in contaminated fields or where food is cooked using arsenic contaminated water (The World Bank, 2005; Ahsan and Del Valls, 2011; Halder et al., 2012). However, the pathway of exposure may vary from region to region depending on human activities, geological composition of the aquifer, and bioavailability of arsenic and other heavy metals (Grissom et al., 1999; Álvarez et al., 2003).

The groundwater arsenic situation in Nadia district is of deep concern in terms of level of arsenic and areal coverage. It is mainly an agricultural based district. As given in the recent district website update, in 2000-2001 the total agricultural land that had irrigation facilities rose to $78.10 \%$. And with the basic mode of irrigation being shallow groundwater, there is an increasing contamination of soil which has raised a concern among the local as well as the people residing nearby. This study reconstructs the initial phase of contamination of shallow as well as the adjacent agricultural fields irrigated with As contaminated water resources in the village of Chakdaha. The main feature of the study area is the differentiation of a high-As aquifer upstream of a low-As aquifer, from which pumping for irrigation is done for the past several decades. Also there is an alternative small scale irrigation by the harvested rainwater which typically contain less than $50 \mu \mathrm{g}$ of As per liter of water and therefore meet the FAO guideline for As in drinking water, whereas As in the groundwater from most shallow tube-wells exceeds the both WHO and FAO limits (WHO, 2007, 2008). Through this study we characterize soils and associated groundwater for the assessment of the severity and extent of As and other heavy metal contamination. And this can be considered essential for devising and planning remedial measures to minimize adverse impacts of groundwater and soil As on human health through agriculture.

Thus, the objective of the present study was: (I) To determine the arsenic and other heavy metals concentrations in soils and in irrigation water in the agricultural area of Chakdah and, (II) To determine the important chemical and physical factors which influence heavy metals concentrations in agricultural soils.

\section{MATERIALS AND METHODS SAMPLING SITE}

Nadia district of West Bengal is highly contaminated with Arsenic (Bhattacharya et al., 2009). Chakdah block (latitude $23^{\circ} 01^{\prime} 15.31^{\prime \prime} \mathrm{N}$ and longitude $88^{\circ} 38^{\prime} 36.86^{\prime \prime} \mathrm{E}$ ) of Nadia district has been chosen for present study where the level of Arsenic in groundwater is frequently exceeding the WHO permissible limit for drinking water and $\mathrm{FAO}$ permissible limit for irrigation water (FAO, 1985; WHO, 1992). Chakdaha block, $65 \mathrm{~km}$ to the north of Kolkata, is located in the Ganges River delta floodplain and bordered on the west side by the Hooghly River, the largest tributary of the Ganges in West Bengal, India. The specific sampling site was Dewli Gram Panchyat (Supplementary Figure 1). The study area is shown in Figure 1 with the sampling locations.

\section{COLLECTION AND PRESERVATION OF SAMPLES}

The collection of pump and pond water along with the agricultural soil cores for each set-up was done over the period of February-May 2013. Water samples were collected in pre-washed bottles of $125 \mathrm{ml}$ from each source. Soon after the collection of water samples, the $\mathrm{pH}$, electrical conductivity (EC), oxidation reduction potential (ORP, with respect to Standard Hydrogen Electrode; Appelo and Postma, 2005) were measured on site using an automatic analyzer of $\mathrm{HACH}$ sensION ${ }^{\mathrm{TM}}$. The water samples were then filtered using Whatman $0.45 \mu$ filter paper and fixed using $\mathrm{HNO}_{3}$ in the field and were taken to laboratory for arsenic and other heavy metal analyses (Loring and Rantala, 1992). For soil samples, soil cores $20 \mathrm{~cm}$ in length were collected using the PVC pipes (van Geen et al., 2006) (Supplementary Figure 2). The soil samples were then taken to laboratory and 1:2.5 soil/solution 


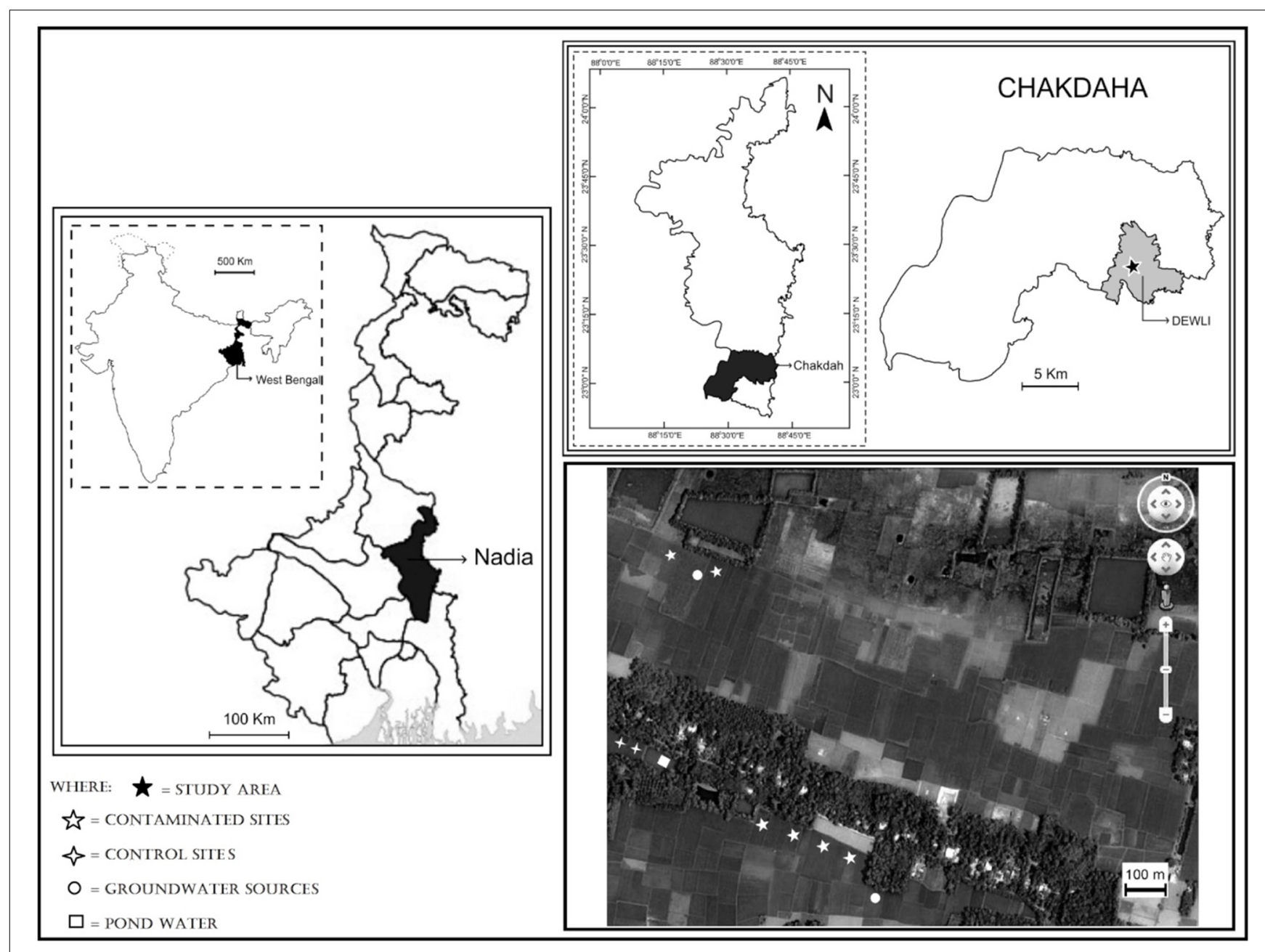

FIGURE 1 | Map of the study area.

ratio of each sample was used to analyze $\mathrm{pH}, \mathrm{EC}$, and ORP using the same instrument following method explained by Hess (1972). The remaining soil samples were kept for drying. Then air-dried soil samples were grounded and passed through $2 \mathrm{~mm}$ sieve and homogenized to make a representative sample (Bose et al., 2008).

\section{CHEMICAL ANALYSIS OF SOIL SAMPLES}

Walkley and Black's method was used for the determination of the percentage by dry mass of organic matter in a soil sample (Walkey and Black, 1934). For the digestion of soil samples for determining heavy metals about $0.5 \mathrm{~g}$ each of the dried samples was taken in digestion tubes and $5 \mathrm{ml}$ of concentrated $\mathrm{HNO}_{3}$ was added to them. The mixtures were allowed to stand overnight under fume hood. The following day, the digestion tubes were placed on a hot plate and heated at $60^{\circ} \mathrm{C}$ for $2 \mathrm{~h}$. Then the tubes were allowed to cool at room temperature. After which $2 \mathrm{ml}$ of concentrated $\mathrm{HClO}_{4}$ and $3 \mathrm{ml}$ of concentrated $\mathrm{H}_{2} \mathrm{SO}_{4}$ were added to it. The tubes were then heated at $160^{\circ} \mathrm{C}$ for about $2-3 \mathrm{~h}$. The heating was stopped when the dense white fume of $\mathrm{HClO}_{4}$ was emitted. The product was then cooled, diluted to $25 \mathrm{ml}$ with de-ionized water and filtered through Whatman $0.45 \mu$ filter papers and finally stored in polyethylene bottles (Bhattacharya et al., 2009). Later the samples were analyzed by ICP-MS (Thermo Scientific Q-ICPMS, XSeries 2) as a chromatographic detector. And the off-line data from the ICP-MS were processed with special chromatographic software (ThermoPlasmaLab) for the arsenic and total metal contents in it.

\section{ANALYSIS OF WATER SAMPLES FOR ARSENIC AND OTHER HEAVY METALS}

The acid fixed filtered water samples were directly analyzed by ICP-MS (Thermo Scientific Q-ICP-MS, XSeries 2) as a chromatographic detector. And the off-line data from the ICP-MS were processed with special chromatographic software (ThermoPlasmaLab) for the arsenic and total metal contents in it (Roychowdhury et al., 2002).

\section{STATISTICAL ANALYSIS}

Statistical analysis was performed using the Sigmaplot (Systat.SigmaPlot.v11.0). Here the correlation analyses were carried out between arsenic concentration and other heavy 
metals concentration in soil to determine the degree of associations. An alpha value of 0.01 was employed for all these analyses.

\section{RESULTS}

\section{PHYSICO-CHEMICAL PROPERTIES OF SOIL AND WATER SAMPLES}

The selected physicochemical properties of the soil and water of the study area are presented in Table 1 (Supplementary Table 1). In the present study it was observed that the paddy cultivated fields have slight higher $\mathrm{pH}$ than the control fields which has led to the desorption of As from the sorption sites in soil with increasing $\mathrm{pH}$ (Khan et al., 2010). The water in both cases was alkaline but more alkalinity was observed in case of the pond water due to the use of pond for domestic purposes, discharge of detergents and lime to neutralize the water as pond is being used for fish farming. Also a marked difference in the oxidation-reduction potential (ORP) was observed in case of the two water sources. The groundwater showed negative value due to the prevalence of reducing condition inside (Turpeinen et al., 1999, 2002). A negative ORP is one of the most important factors owing to the release of arsenic in the aquifers. Also the present irrigation system of the agricultural land did not affect the general properties of the soils, as no significant differences were found in the soil $\mathrm{pH}, \mathrm{EC}$, or $\mathrm{Zn}$, or organic carbon (OC) in both control and contaminated agricultural field.

\section{ARSENIC AND OTHER HEAVY METALS IN SOIL AND WATER SAMPLES}

The concentrations of arsenic and other heavy metals determined in the soil and water are mentioned in Table 2 (Supplementary). Figure 2A shows the comparison of arsenic concentration between control and the contaminated agricultural soil. The concentration of arsenic $(9.67 \pm 0.24 \mathrm{mg} / \mathrm{kg})$ and other heavy metals in the control field were within the normal range (O'Neil, 1995). Whereas the agricultural soil of the study area has become highly contaminated with arsenic ( $>54 \mathrm{mg} / \mathrm{kg}$ ) due to the continuous use of arsenic rich shallow groundwater for irrigation purpose.

The study showed (Figure 2B) that the concentration of arsenic even in the pond water was above than the safety standards $(32.63 \pm 0.88 \mu \mathrm{g} / \mathrm{l})$ given by WHO $(10 \mathrm{ppb})$ although below than ISI (Indian Standard of Bureau) standard (50 ppb). The sources of the control water, i.e., pond water are not only rain water, but the supply from the shallow tube well during the dry season. Various climatic and geomorphic condition of an area, such as rainfall, runoff, rate of infiltration, and the groundwater level and its fluctuation, also affect the mobility and redistribution of As (Bhattacharya et al., 2002). Other heavy metals concentrations were much below than permissible limits given by $\mathrm{WHO}$ ( $\mathrm{WHO}$, 2007; Yadav et al., 2013), whereas the average arsenic concentration in the groundwater of the study area is $76.43 \mu \mathrm{g} / \mathrm{l}$, which is much above the prescribed limits by WHO and ISI, affecting the soil quality adversely.

Table 1 | Showing the physico-chemical parameters of the soil and water samples.

\begin{tabular}{|c|c|c|c|c|}
\hline Parameters & $\mathrm{pH}$ mean $\pm S D$ & $\mathrm{EC}(\mu \mathrm{S} / \mathrm{cm})$ mean $\pm S D$ & ORP $(m V)$ mean $\pm S D$ & $\% O C$ mean $\pm S D$ \\
\hline Paddy cultivated fields $(n=150)$ & $8.10 \pm 0.24$ & $22.09 \pm 0.37$ & $166.09 \pm 2.83$ & $1.731 \pm 0.06$ \\
\hline Groundwater $(n=40)$ & $7.63 \pm 0.11$ & $231.59 \pm 1.82$ & $-125.03 \pm 1.48$ & NA \\
\hline
\end{tabular}

Where n, no. of samples; SD, standard deviation; EC, Electrical Conductivity; $\mu$ S, micro Siemen; ORP, Oxidation-Reduction Potential; mV, milli Volts; OC, Organic Carbon; \%, percentage; NA, Not applicable.
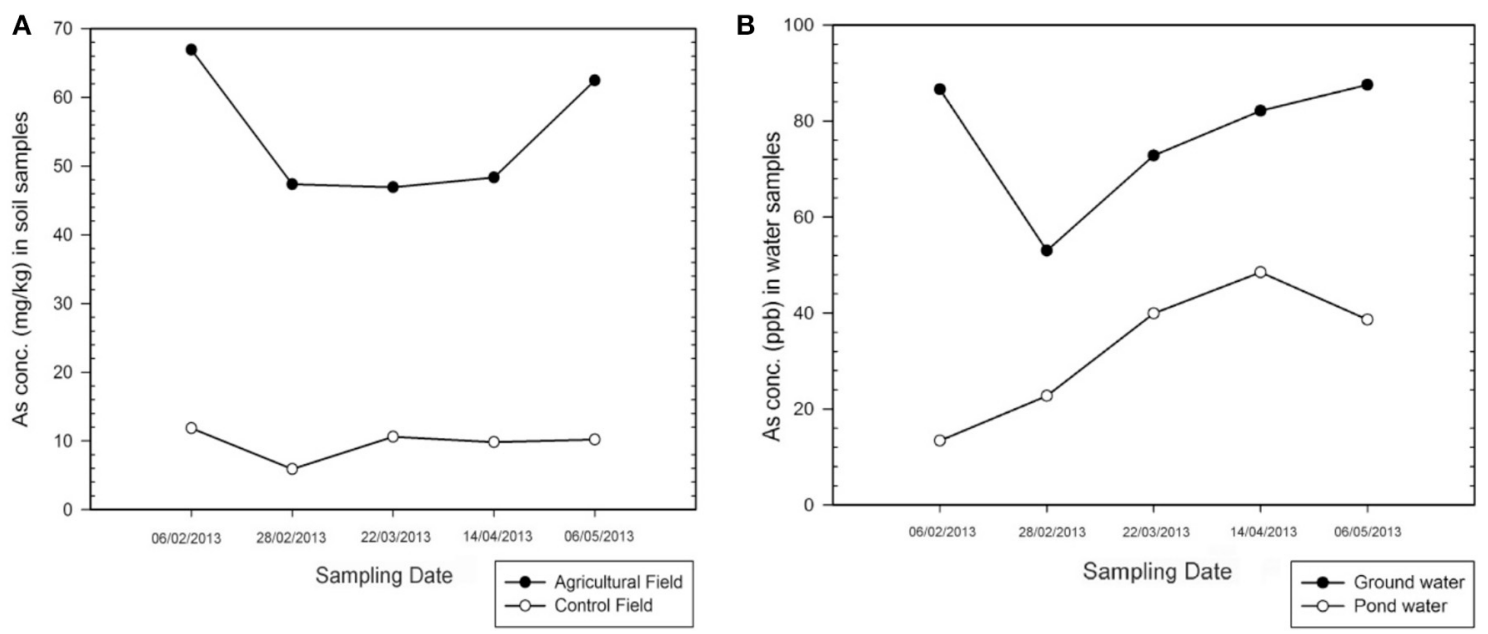

FIGURE 2 | Graph showing comparison of As concentration between (A) control and contaminated soil; and (B) pond water and shallow groundwater. 


\section{CORRELATION ANALYSES}

Figure 3 shows the correlation analysis done for As concentration in soil and water of the study area (Supplementary Table 3). It was observed that the As concentration in soil shows a significant correlation with As concentration in water (Alam and Sattar, 2000), specially As rich irrigation water can enrich the As level in

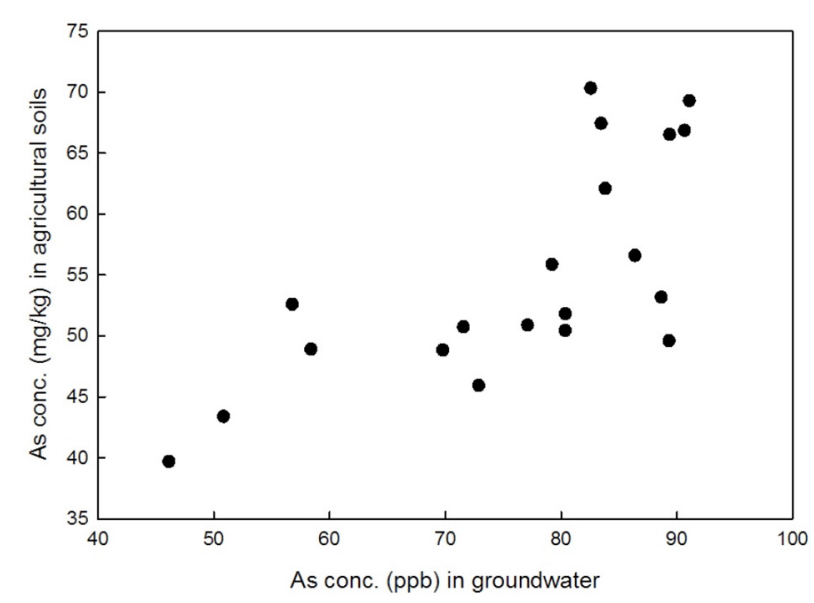

FIGURE 3 | Correlation plot between arsenic in shallow groundwater vs. arsenic in soil, collected from the agricultural soil.
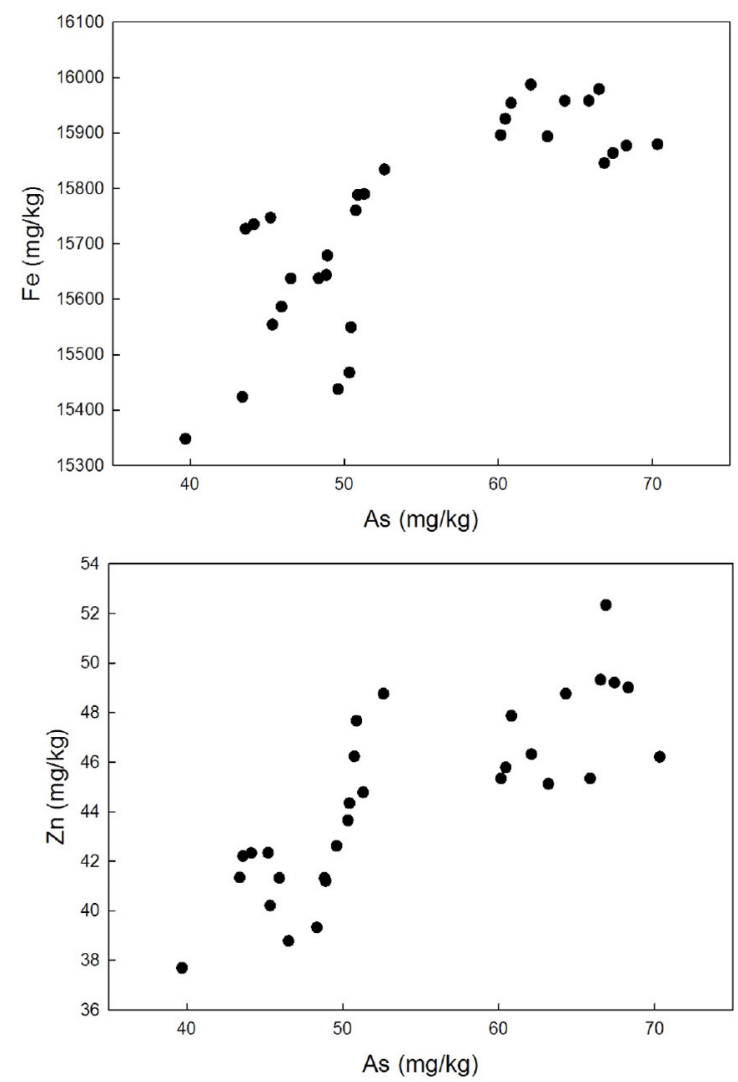

agricultural soil up to five times than normal (Saha and Ali, 2007; Ahsan et al., 2008) which found in our study also. The correlation found in the study was of the value of $r=0.71, p<<0.01$, although a very fair correlation was observed in the study conducted by Roychowdhury et al. (2002) in West Bengal. Also the present irrigation system of the agricultural land did not affect the general properties of the soils, as no significant differences were found in the soil $\mathrm{pH}, \mathrm{EC}$, or $\mathrm{Zn}$, or organic carbon (OC) in both control and contaminated agricultural field.

The correlation analyses were carried out, the results of which are shown in Figure 4. The result showed significant correlation between As and Fe $(r=0.79, p<<0.01)$, As and $\mathrm{Mn}(r=$ $0.79, p<<0.01)$, As and $\mathrm{Zn}(r=0.80, p<<0.01)$, and As and $\mathrm{Cu}(r=0.80, p<<0.01)$. Similar results were obtained by the study conducted by Roychowdhury et al. (2002) in Murshidabad district, India.

\section{DISCUSSION}

The values of selected physicochemical properties of the soil in each case for both control fields as well as paddy cultivated contaminated fields were more than the study conducted by Bhattacharya et al. (2009) in the nearby areas. From the previous studies, the fact has been well established that As(III) and As(V) sorb rapidly and extensively onto a variety of metal (e.g., Fe, Al) (hydro)oxides, carbonates, organic matter, and clay minerals and the process is pH-dependent (Ali, 2003; Ali et al., 2003; Goh and
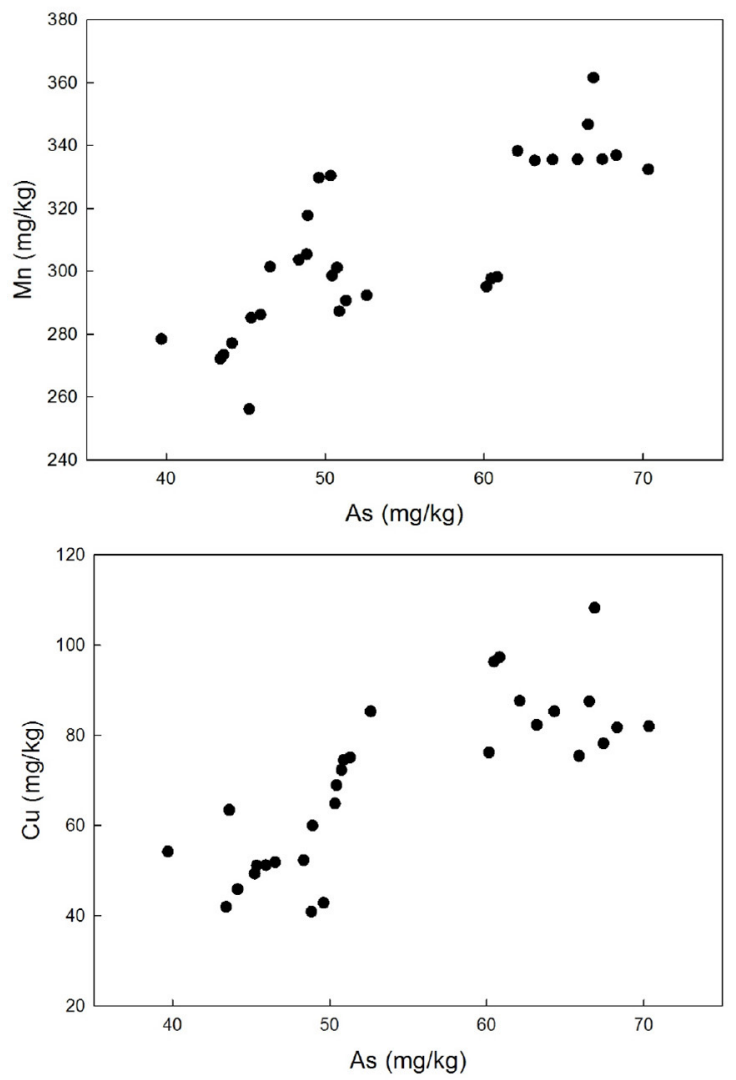

FIGURE 4 | Correlation plots between arsenic and other heavy metals in soil, collected from paddy cultivated agricultural field. 
Lim, 2005; Wang and Mulligan, 2006). The adsorption of As (III) and As (V) by Fe oxides is influenced by $\mathrm{pH}$. Depending on the isoelectric point of the adsorbent solid, the adsorption of As (V) decreases with increasing $\mathrm{pH}$ (Hisa et al., 1994). However, the adsorption of As (III) increases with increasing $\mathrm{pH}$. The Fe oxides also have a $\mathrm{pH}$ dependent charge. The point of zero charge (pzc) of Fe oxide occurs at approximately $\mathrm{pH} \mathrm{8,} \mathrm{where} \mathrm{As} \mathrm{(III)} \mathrm{and} \mathrm{As}$ (V) are adsorbed to both positively and negatively charged surface (Kosmulski, 2009). As pH increases in any system, As (V) is desorbed from $\mathrm{Fe}(\mathrm{OH})_{3}$, and the rate of desorption for As (V) can be quite high (Fuller et al., 1993). The similar trend was observed in the comparative study of soil samples. Whereas in case of groundwater, the ORP showed negative value due to the prevalence of reducing condition inside. Arsenate is much more strongly absorbed than arsenite because of its greater negative charge at the same $\mathrm{pH}$ (Ali and Ahmed, 2003). It was also confirmed that the groundwater is highly contaminated with arsenic thus similar to the result found by Marin et al. (1993) where the water soluble arsenic concentration had an inverse relation to the redox.

The concentrations of As in non-contaminated soils range from 0.1 to $10 \mathrm{mg} / \mathrm{kg}$ (Kabata-Pendias and Pendias, 1992). Roychowdhury et al. (2002) reported that the mean As concentration of agricultural lands of West Bengal, was $10.7 \mathrm{mg} / \mathrm{kg}$, with a range of $3.3-31.6 \mathrm{mg} / \mathrm{kg}$. In the present study, As content in examined agricultural soils was higher than the studies reported from Bangladesh and West Bengal. The mean value for arsenic was found to be $54.40 \mathrm{mg} / \mathrm{kg}$ in this study. From the data retrieved and shown in Table 2, it can be seen that the arsenic concentration of the paddy cultivated fields are much above the maximum acceptable limit for agricultural soils i.e., $20 \mathrm{mg} / \mathrm{kg}$ as given by the European Community (Rahman et al., 2007). The arsenic concentration is at an alarming level and can now easily be hyperaccumulated by the crops (Ali, 2003; Liu et al., 2005; Ahsan and Del Valls, 2011).

Correlation analysis showed a significant correlation with the heavy metals which is similar as found by the study carried out by Roychowdhury et al. (2002) in Domkal area of West Bengal. Ahsan et al. (2008) also found a significant correlation although it was very weak between As and Fe in both the study areas. Similar to our result, a significant correlation was observed between As with Fe and Mn in the study conducted by Cai et al. (2002) in South Florida. Based on the studies conducted by many authors it is expected that surface soil of agricultural land accumulates arsenic from contaminated water due to its high affinity with metal oxides/hydroxides in soil (Ahsan and Del Valls, 2011). Soil organic matter has not any significant role in As sorption in soil, especially in presence of effective sorbents such as hydrous Fe oxides (Livesey and Huang, 1981; Wenzel et al., 2002).

There were only 15,700 shallow tube wells in 1976-1977 and their count rose to 64,637 by $2000-2001$ (www.nadia.gov.in). And as the irrigation in the area is mainly dependent on the shallow groundwater, it was quite important to assess the arsenic and other heavy metals concentration in the groundwater as well as agricultural soils. Rice is a wetland plant, which requires a huge amount of water for cultivation, which leads to increase the mobility of As in the irrigation land (Halder et al., 2013), thus the concentration of arsenic and other heavy metals directly affects the quality of soil as well as quality of crop. Boro (dry season) rice requires approximately $1000 \mathrm{~mm}$ of irrigation water per season, which is promoting by $1 \mu \mathrm{g} / \mathrm{g}$ per year soil As concentration due to irrigation with As contaminated water (Meharg and Rahman, 2003). Although the long-term trends of As concentrations in irrigated paddy soils are difficult to assess due to large spatial heterogeneity and temporal variability (Dittmar et al., 2007). The average arsenic concentration in the groundwater of the contaminated area $122.57 \mu \mathrm{g} / \mathrm{l}$, is much above the prescribed limits by WHO, i.e., $10 \mu \mathrm{g} / \mathrm{L}$. The results were similar to the study conducted by Bhattacharya et al. (2009) in Chakdah block; where the levels were also above the WHO standards. This high concentration of arsenic in the groundwater clearly justifies the high soil arsenic contamination. Many arsenic-contaminated sites are also contaminated with other heavy metals namely, $\mathrm{Cu}, \mathrm{Zn}$, and $\mathrm{Ni}$ (Chirenje et al., 2003) though which is not prevalent in our study. So it's essential to focus on evaluation of metal addition on arsenic distribution which will shed more light on remediation of arsenic contaminated soils. It was also observed that the concentration of other heavy metals mentioned in Table 2, were under the safe limits given by WHO. But, with time the other metal concentration can be increased like As.

\section{CONCLUSION}

With groundwater-based water supply and irrigation projects being implemented across arsenic affected regions, there is a serious need to address this issue. Based on our investigation it can be clearly seen that the level of As in shallow groundwater in the study area is very much above the WHO permissible limit of $10 \mu \mathrm{g} / \mathrm{l}$. Eventually, the soils build-up of As is be due to the

Table 2 | Concentration of arsenic and other heavy metals $(\mathrm{mg} / \mathrm{kg})$ in soils and water $(\mu \mathrm{g} / \mathrm{l})$ samples.

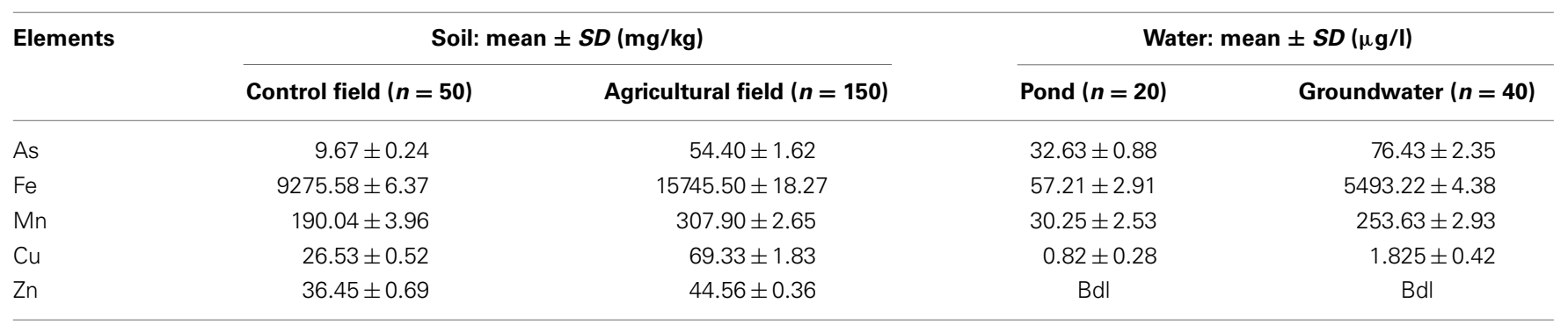

bdl, below detection limits. 
long term and continuous use of the contaminated groundwater for irrigation purposes. Apart from arsenic other heavy metals are also posing threat to various life forms from the mode of transfer that is agriculture. With time these are also getting accumulated in the fields and contaminants can be accumulated in the human through bioaccumulation. There is no regulating body in India to check As in food grains as this is a developing country and with deficit of food. This is also a matter of concern that the people who live in the As contaminated area are not only at risk but other people also from other part of India are in risk as they are consuming As contaminated food produced in these areas. Thus, there is a serious immediate concern for the people and other life forms regarding the poisoning through crops and drinking water as well. Major steps are needed to be taken, which mainly involve the active institutional integration of water supply with water management concerns, coming up with concrete actions when arsenic is detected in a certain area, overcoming the political economy constraints and mitigation activities, a strategic research agenda to answers such issues as the dose-response relationships for arsenic, study of arsenic in the food chain, and geohydrological and hydrochemical research.

\section{ACKNOWLEDGMENTS}

The authors are thankful to IISER Kolkata for providing them infrastructure as well as all the villagers of Sarapur for their cooperation and help to conduct the field experiments smoothly. Sutapa Bose is thankful to Department of Science and Technology (DST) Government of India for providing her Ramanujan Fellowship Research Grant, (SR/S2/RJM-09/2011) to carry this research. Anamika Shrivastava is thankful to DST INSPIRE Fellowship (IF130211) in the form of Junior Research Fellow (JRF), Anil Barla is thankful to Council of Scientific and Industrial Research (CSIR) for providing him JRF during this work and Himanshu Yadav is thankful to DST for providing the fund in the form of INSPIRE Scholarship. Also the authors are thankful to Dr. Manoj K. Jaiswal for providing partial laboratory support and to Abhay Kumar Singh (IAS Fellow) and Sukanya Acharya (IISER K Summer Fellow) for initiating the field experiment.

\section{SUPPLEMENTARY MATERIAL}

The Supplementary Material for this article can be found online at: http://www.frontiersin.org/journal/10.3389/fenvs.2014. 00050/abstract

\section{REFERENCES}

Acharyya, S. K., Chakraborty, P., Lahiri, S., Raymahashay, B. C., Guha, S., and Bhowmik, A. (1999). Arsenic poisoning in the Ganges delta. Nature 401, 545. doi: $10.1038 / 44052$

Ahsan, D. A., and Del Valls, T. A. (2011). Impact of arsenic contaminated irrigation water in food chain: an overview from Bangladesh. Int. J. Environ. Res. 5, 627-638.

Ahsan, D. A., Del Valls, A. C., and Blasco, J. (2008). Distribution of arsenic and trace metals in the floodplain agricultural soil of bangladesh. Bull. Environ. Contam. Toxico. 82, 11-15. doi: 10.1007/s00128-008-9502-x

Alam, M. B., and Sattar, M. A. (2000). Assessment of arsenic contamination in soils and waters in some areas of Bangladesh. Water Sci. Technol. 42, 185-193.

Ali, M. (2003). Review of Drilling and Tubewell Technology for Groundwater Irrigation. Dhaka: The University Press Limited.
Ali, M. A., and Ahmed, M. F. (2003). "Environmental chemistry of arsenic," in Arsenic Contamination: Bangladesh Perspective, ed M. F. Ahmed (Dhaka: ITN-Bangladesh), 21-42.

Ali, M. A., Badruzzaman, A. B. M., Jalil, M. A., Hossain, M. D., Ahmed, M. F., Masud, A. A., et al. (2003). "Arsenic in plant-soil environment in Bangladesh," in Fate of Arsenic in the Environment. Proceedings of the International Symposium on Fate of Arsenic in the Environment, eds M. F. Ahmed, M. A. Ali, and Z. Adeel (Dhaka: ITN Centre, BUET), 147-159.

Álvarez, E., Fernández Marcos, M. L., Vaamonde, C., and Fernández-Sanjurjo, M.J. (2003). Heavy metals in the dump of an abandoned mine in Galicia (NW Spain) and in the spontaneously occurring vegetation. Sci. Total Environ. 313, 185-197. doi: 10.1016/S0048-9697(03)00261-4

Appelo, C. A. J., and Postma, D. (2005). Geochemistry, Groundwater and Pollution, 2nd Edn. Leiden: A A Balkema.

Appelo, C. A. J., Van derWeiden, M. J. J., Tournassat, C., and Charlet, L. (2002). Surface complexation of ferrous iron and carbonate on ferrihydrite and the mobilization of arsenic. Environ. Sci. Technol. 36, 3096-3103. doi: 10.1021/es010130n

Bhattacharya, P., Jacks, G., Frisbie, S. H., Smith, E., Naidu, R., and Sarkar, B. (2002). "Arsenic in the environment: a global perspective," in Handbook of Heavy Metals in the Environment, ed B. Sarker (New York, NY: Marcel Dekker Inc.), 147-215.

Bhattacharya, P., Samal, A. C., Majumdar, J., and Santra, S. C. (2009). Transfer of arsenic from groundwater and paddy soil to rice plant (Oryza sativa L.): a micro level study in West Bengal, India. World J. Agric. Sci. 5, 425-431.

Bose, S., Chandrayan, S., Rai, V., Bhattacharyya, A. K., and Ramanathan, A. L. (2008). Translocation of metals in pea plants grown on various amendment of electroplating industrial sludge. Bioresour. Technol. 99, 4467-4475. doi: 10.1016/j.biortech.2007.08.020

Cai, Y., Cabrera, J. C., Georgiadis, M., and Jayachandran, K. (2002). Assessment of arsenic mobility in the soils of some golf courses in South Florida. Sci. Total Environ. 291, 123-134. doi: 10.1016/S0048-9697(01)01081-6

Chakraborti, D., Basu, G. K. and Biswas, B. K. (2001). "Characterization of arsenicbearing sediments in the Gangetic delta of West Bengal, India," in Arsenic Exposure and Health Effects IV, eds W. R. Chappell, C. O. Abernathy, and R. A. Calderon (Oxford: Elsevier Science), 27-52.

Chakraborti, D., Ghorai, S. K., Das, B., Pal, A., Nayak, B., and Shah, B. A. (2009). Arsenic exposure through groundwater to the rural and urban population in the allahabad-kanpur track in the upper ganga plain\supplementary informat. J. Environ. Monit. 11, 1455-1459. doi: 10.1039/ b906584a

Chauhan, V. S., Yunus, M., and Sankararamakrishnan, N. (2012). Geochemistry and mobilization of arsenic in Shuklaganj area of Kanpur-Unnao district, Uttar Pradesh, India. Environ. Monit. Assess. 184, 4889-4901. doi: 10.1007/s10661011-2310-5

Chirenje, T., Ma, L. Q., Szulezewski, M., Littell, R., Portier, K. M., and Zillioux, E. (2003). Arsenic distribution in Florida urban soils: comparison between Gainesville and Miami. J. Environ. Qual. 32, 109-119. doi: $10.2134 /$ jeq2003.1090

Chowdhury, T. R., Basu, G. K., Mandal, B. K., Biswas, B. K., and Samanta, G. (1999). Arsenic poisoning in the Ganges delta. Nature 401, 545-546

Cullen, W. R., and Reimer, K. J. (1989). Arsenic speciation in the environment. Chem. Rev. 89, 713-764. doi: 10.1021/cr00094a002

Das, D., Basu, G., Chowdhury, T. R., and Chakraborty, D. (1995). "Borehole soil-sediment analysis of some As affected areas," in Proceedings of International Conferences on Arsenic in Groundwater: Cause, Effect, and Remedy (Calcutta).

Das, D., Samanta, G., Mandal, B. K., Roychowdhury, T., Chanda, C. R., Chowdhury, P. R., et al. (1996). Arsenic in groundwater in six districts of West Bengal, India. Environ. Geochem. Health. 18, 5-15. doi: 10.1007/BF01757214

Dermatas, D., Moon, D. H., Menounou, N., Meng, X., and Hires, R. (2004). An evaluation of arsenic release from monolithic solids using a modified semi-dynamic leaching test. J. Hazard. Mater. 116, 25-38. doi: 10.1016/j.jhazmat.2004.04.023

Dittmar, J., Voegelin, A.,Roberts, L. C., Hug, S. J., Saha, G. C., Ali, M. A., et al. (2007). Spatial distribution and temporal variability of arsenic in irrigated rice fields in Bangladesh. 2. Paddy soil. Environ. Sci. Technol. 41, 5967-5972. doi: $10.1021 /$ es0702972 
FAO. (1985). Water quality guidelines for maximum crop production. Food and Agricultural Organization/UN. Available online at: www.fao.org/docrep/ T0551E.2006/9/13

Fendorf, S., Michael, H. A., and van Geen, A. (2010). Spatial and temporal variations of groundwater arsenic in South and Southeast Asia. Science 328, 1123. doi: $10.1126 /$ science. 1172974

Fuller, C. C., Davies, J. A., and Waychunas, G. A. (1993). Surface chemistry of ferrihydrite: part 2. Kinetics of arsenate adsorption and coprecipitation. Geochim. Cosmochim. Acta 57, 2271-2282.

Goh, K. H., and Lim, T. T. (2005). Arsenic fractionation in a fine soil fraction and influence of various anions on its mobility in the subsurface environment. Appl. Geochem. 20, 229-239. doi: 10.1016/j.apgeochem.2004. 08.004

Grissom, R. E., Abernathy, C. O., Susten, A. S., and Donohue, J. M. (1999). "Estimating total arsenic exposure in the united states in arsenic exposure and health effects," in Proceedings of the Third International Conference on Arsenic Exposure and Health Effects, eds C. Chappell, C. O. Abernathy, and R. Calderon (Amsterdam: Elsevier), 51-57.

Halder, D., Bhowmick, S., Biswas, A., Chatterjee, D., Nriagu, J., Mazumdar, D. N. G., et al. (2012). Risk of arsenic exposure from drinking water and dietary components: implications for risk management in rural Bengal. Environ. Sci. Technol. 47, 1120-1127. doi: 10.1021/ es303522s

Halder, D., Bhowmick, S., Biswas, A., Mandal, U., Nriagu, J., Mazumdar, D. N. G., et al. (2013). Consumption of brown rice: a potential pathway for arsenic exposure in rural Bengal. Environ. Sci. Technol. 46, 4142-4148. doi: $10.1021 /$ es204298

Harvey, C. F., Swartz, C. H., Badruzzaman, A. B. M., Keon-Blute, N., Yu, W., Ali, M. A., et al. (2002). Arsenic mobility and groundwater extraction in Bangladesh. Science 298,1602-1606. doi: 10.1126/science. 1076978

Hess, P. R. (1972). A Text Book of Soil Chemical Analysis. New York, NY: Chemical Publishing Co., Inc.

Hisa, T. H., Lo, S. L., Lin, C. F., and Lee, D. Y. (1994). Characterization of arsenate adsorption on hydrous iron oxide using chemical and physical methods. Colloids Surf. A Physicochem. Eng. Aspect 85, 1-7.

Hopenhayn, C. (2006). Arsenic in drinking water: impact on human health. Elements 2,103-107. doi: 10.2113/gselements.2.2.103

Hudson-Edwards, K. A., Houghton, S. L., and Osborn, A. (2004). Extraction and analysis of arsenic in soils and sediments. Trends Anal. Chem. 23, 745-752. doi: 10.1016/j.trac.2004.07.010

Kabata-Pendias, A., and Pendias, H. (1992). Trace Elements in Soil and Plants, 2nd $E d n$. Boca Raton, FL: CRC

Khan, M. A., Stroud, J. L., Zhu, Y. G., Mcgrath, S. P., and Zhao, F. J. (2010). Arsenic bioavailability to rice is elevated in Bangladesh paddy soils. Environ. Sci. Technol. 44, 8515-8521. doi: 10.1021/es $101952 \mathrm{f}$

Kosmulski, M. (2009). pH-dependent surface charging and points of zero charge. IV. Update and new approach. J. Colloid Interface Sci. 337, 439-448 doi 10.1016/j.jcis.2009.04.072

Liu, W. J., Zhu, Y. G., and Smith, F. A. (2005). Effects of iron and manganese plaques on arsenic uptake by rice seedlings (Oryza sativa) grown in solution culture supplied with arsenate and arsenite. Plant Soil 277, 127-138. doi: $10.1007 /$ s11104-005-6453-4

Livesey, N. T., and Huang, P. M. (1981). Adsorption of arsenate by soils and its relation to selected chemical properties and anions. Soil Sci. 131, 88-94. doi: 10.1097/00010694-198102000-00004

Loring, D. H., and Rantala, R. T. T. (1992). Manual for the geochemical analyses of marine sediments and suspended particulate matter. Earth Sci. Rev. 32, 235-283. doi: 10.1016/0012-8252(92)90001-A

Marin, A. R., Masscheleyn, P. H., and Patrick, W. H. (1993). Soil redox-pH stability of arsenic species and its influence on arsenic uptake by rice. Plant Soil. 152, 245-253. doi: 10.1007/BF00029094

Meharg, A. A., and Rahman, M. (2003). Arsenic contamination of Bangladesh paddy field soils: implications for rice contribution to arsenic consumption. Environ. Sci. Technol. 37, 229-234. doi: 10.1021/ es0259842

Nickson, R., McArthur, J., Burgess, W., Ahmed, K. M., Ravenscroft, P., Rahman,ñ M. (1998). Arsenic poisoning of Bangladesh groundwater. Nature 395, $338-338$
Ning, R. Y. (2002). Asenic ermoval by reverse osmosis. Desalinisation 143, 237-241. doi: 10.1016/S0011-9164(02)00262-X

O’Neil, P. (1995). "Heavy metals in soils," in Arsenic, ed B. J. Alloway (London: Blackie Academic and Professional Arsenic), 105-121.

Polizzotto, M. L., Kocar, B. D., Benner, S. G., Sampson, M., Fendorf, S. (2008). Near-surface wetland sediments as a source of arsenic release to ground water in Asia. Nature 454, 505-508. doi: 10.1038/ nature 07093

Rahman, M. A., H., Hasegawa, M. M., Rahman, M. A., Rahman, and Miah, M. A. M. (2007). Accumulation of arsenic in tissues of rice plant (Oryza sativa L.) and its distribution in fractions of rice grain. Chemosphere 69, 942-948. doi: 10.1016/j.chemosphere.2007.05.044

Ravenscroft, P., Brammer, H., and Richards, K. (2009). Arsenic Pollution: A Global Synthesis Chichester: RGS-IBG Book Series, Wiley-Blackwell.

Roychowdhury, T., Basu, G. K., Mandal, B. K., Biswas, B. K., Samanta, G., Chowdhury, U. K., et al. (1999). Arsenic poisoning in the Ganges delta. Nature 401, 545-546.

Roychowdhury, T., Uchino, T., Tokunaga, H., and Ando, M. (2002). Arsenic and other heavy metals in soils from an arsenic-affected area of West Bengal, India. Chemosphere 49, 605-618. doi: 10.1016/S0045-6535(02) 00309-0

Sadiq, M. (1997). Arsenic chemistry in soils: an overview of thermodynamic predictions and field observations. Water Air Soil Pollut. 93, 117-136. doi: 10.1007/BF02404751

Saha, G. C., and Ali, M. A. (2007). Dynamics of arsenic in agricultural soils irrigated with arsenic contaminated groundwater in Bangladesh. Sci. Total Environ. 379, 180-189. doi: 10.1016/j.scitotenv.2006. 08.050

Smedley, P. L., and Kinniburgh, D. G. (2002). A review of the source, behaviour and distribution of arsenic in natural waters. Appl. Geochem. 17, 517-568. doi: 10.1016/S0883-2927(02)00018-5

The World Bank. (2005). Arsenic Contamination of Groundwater in South and East Asian Countries. Vol. I, Policy Report. (Washington, DC: Office of the Publisher, The World Bank).

Turpeinen, R. R., Panstar-Kallio, M., Haggblom, M., and Kairesalo, T. (1999). Influence of microbes on the mobilization, toxicity and biomethylation of arsenic in soil. Sci. Total Environ. 236, 173-180. doi: 10.1016/S00489697(99)00269-7

Turpeinen, R. R., Panstar-Kallio, M., Haggblom, M., and Kairesalo, T. (2002). Role of microbes in controlling the speciation of arsenic and production of arsines in contaminated soils. Sci. Total Environ. 285, 133-145. doi: 10.1016/S0048 9697(01)00903-2

van Geen, A., Zheng, Y., Cheng, Z., Yi, H., Dhar, R. K., Garnier, J. M., et al. (2006). Impact of irrigating rice paddies with groundwater containing arsenic in Bangladesh. Sci. Total Environ. 367, 769-777. doi: 10.1016/j.scitotenv.2006.01.030

Walkey, A., and Black, I. A. (1934). An examination of the degtjareff method for determining soil organic matter and a proposed modification of the chromic acid titration method. Soil Sci. 37, 29-38. doi: 10.1097/00010694-19340100000003

Wang, S., and Mulligan, C. N. (2006). Effect of natural organic matter on arsenic release from soils and sediments into groundwater. Environ. Geochem. Health 28, 197-214. doi: 10.1007/s10653-005-9032-y

Wenzel, W. W., Brandstetter, A., Wutte, H., Lombi, E., Prohaska, T., Stingeder, G., et al. (2002). Arsenic in field-collected soil solutions and extracts of contaminated soils and its implication to soil standards. J. Plant Nutr. Soil Sci. 165, 221-228.

Winkel, L., Berg, M., Amini, M., Hug, S. J., Johnson, C. A. (2008). Predicting Groundwater Arsenic Contamination in Southeast Asia from Surface Parameters. Eawag, Swiss Federal Institute of Aquatic Science and Technology. Available online at: www.nadia.gov.in/Agriculture/agriculture.html (Accessed September $28,2013)$.

WHO. (1992). Guideline for Drinking Water Quality, Recommendation, Vol. 1, 2nd Edn. (Geneva: World Health Organization), 41.

WHO. (2000). "Chapter 6: Arsenic," in Air Quality Guidelines, 2nd Edn. Copenhagen: WHO Regional Office for Europe.

WHO. (2007). Joint FAO/WHO Expert Standards Program Codex Alimentation Commission. Geneva. Available online at: http://www.who.int (Accessed September 10, 2012). 
WHO. (2008). Guidelines for Drinking Water Quality-Vol.1: Reccomendation, 3rd $E d n$. Available online at: http://www.who.int/water_sanitation_health.

Yadav, A., Yadav, P. K., and Shukla, D. N. (2013). Investigation of heavy metal status in soil and vegetables grown in urban areas of Allahabad, Uttar Pradesh, India. Int. J. Sci. Res. Publ. 3.

Conflict of Interest Statement: The authors declare that the research was conducted in the absence of any commercial or financial relationships that could be construed as a potential conflict of interest.

Received: 08 June 2014; accepted: 04 November 2014; published online: 19 November 2014.
Citation: Shrivastava A, Barla A, Yadav H and Bose S (2014) Arsenic contamination in shallow groundwater and agricultural soil of Chakdaha block, West Bengal, India. Front. Environ. Sci. 2:50. doi: 10.3389/fenvs.2014.00050

This article was submitted to Groundwater Resources and Management, a section of the journal Frontiers in Environmental Science.

Copyright (c) 2014 Shrivastava, Barla, Yadav and Bose. This is an open-access article distributed under the terms of the Creative Commons Attribution License (CC BY). The use, distribution or reproduction in other forums is permitted, provided the original author(s) or licensor are credited and that the original publication in this journal is cited, in accordance with accepted academic practice. No use, distribution or reproduction is permitted which does not comply with these terms. 